\title{
THE PREVALENCE OF HIGH ANXIETY AND SUBSTANCE USE IN UNIVERSITY STUDENTS IN THE REPUBLIC OF MACEDONIA
}

\author{
Sanja Manchevska, Jasmina Pluncevic-Gligoroska
}

Institute of Physiology and Anthropology, Medical Faculty, Ss. Cyril and Methodius University, Skopje, R. Macedonia

Corresponding Author: Sanja Manchevska, Institute of Physiology and Anthropology, Medical Faculty, 50. Divizija bb, 1000 Skopje, R. Macedonia, Tel: + 389 (0)2 31117 74, E-mail: sanjamancevska@gmail.com

\begin{abstract}
Aim: The aim of the study was to determine the prevalence of high anxiety and substance use among university students in the Republic of Macedonia.

Material and methods: The sample comprised 742 students, aged 18-22 years, who attended the first (188 students) and second year studies at theMedical Faculty (257), Faculty of Dentistry (242), and Faculty of Law (55) within Ss. Cyril and Methodius Universityin Skopje. As a psychometric test the Beck Anxiety Inventory (BAI) was used. It is a self-rating questionnaire used for measuring the severity of anxiety. A psychiatric interview was performed with students with BAI scores $>25$. A self-administered questionnaire consisted of questions on the habits of substance (alcohol, nicotine, sedative-hypnotics, and illicit drugs) use and abuse was also used. For statistical evaluation Statistica 7 software was used.

Results: The highest mean BAI scores were obtained by first year medical students $(16.8 \pm 9.8)$. Fifteen percent of all students and $20 \%$ of first year medical students showed high levels of anxiety. Law students showed the highest prevalence of substance use and abuse.

Conclusion: High anxiety and substance use as maladaptive behaviours among university students are not systematically investigated in our country. The study showed that students show these types of unhealthy reactions, regardless of the curriculum of education. More attention should be paid to students in the early stages of their education. A student counselling service which offers mental health assistance needs to be established within University facilities in R. Macedonia alongside the existing services in our health system.
\end{abstract}

Key words: anxiety, BAI, substance use, student counselling service.

\section{Introduction}

Higher education is a period of life in which the mental wellbeing of university students is vulnerable to the potentially harmful effects of many stressors. These effects can lead to the adoption and maintenance of maladaptive behaviours, such as anxiety and depressive symptoms, substance use and abuse, and poor academic achievement in students [1-8]. Data from cross-sectional studies suggest that high anxiety levels and depressive symptoms, which are negatively correlated with emotional stability and positively correlated with stress vulne- rability, are common health problems in students all over the world [9]. Data from longitudinal studies suggest that these symptoms persist over a longer period of time, but the students do not receive appropriate help [1, 10-12]. Higher rates of high anxiety, depression and other symptoms of psychological distress have been reported for medical and law students in countries all over the world $[2,6,8,13,14]$.

According to epidemiological data, anxiety disorders, mood disorders and substance abuse are the most frequent psychiatric disorders. The age of 10 to 25 years is most sensitive to the 
development of some type of anxiety disorder [15]. There is a time correlation between the onset of clinically manifested anxiety disorder and the development of depression in adolescents and clinical patients, suggesting that clinically manifest anxiety disorder precedes the onset of clinically manifest depression over a period of approximately two years $[16,17]$. Therefore, it is very important to focus our attention on signs and symptoms (physiological, emotional and behavioral) of sub-clinical anxiety and maladaptive behaviours (substance use and abuse) which are certain signs of distress in adolescents and young adults, especially in early stages of higher education, in order to prevent future negative development.

The aim of the study was to estimate the levels of anxiety and the prevalence of substance use in university students in the Republic of Macedonia in the early stages of education.

\section{Material and methods}

The study took place in Ss. Cyril and Methodius University, Skopje, the oldest and the biggest university in the Republic of Macedonia. It was conducted with first and the second year students at the Faculty of Medicine, and with the second year students at the Faculty of Dentistry and the Faculty of Law. We evaluated 742 students, who were attending the first (188) and second years of the Medical Faculty (257), the Faculty of Dentistry (242) and the Faculty of Law (55). For the purpose of clinical and psychological evaluation of the levels and perceived symptoms of anxiety we used the Beck Anxiety Inventory - BAI [18] in the form of a self-rating questionnaire administered to the students in classroom settings. BAI consists of 21 questions related to various aspects of anxiety.
The intensity of perceived anxiety was rated from 0 to 3 , with 0 representing the least serious and 3 the most serious symptoms. BAI scores from 0-7 were ranked as normal anxiety level, 8-25 as moderate; and 26-63 as high anxiety.

We also used a self-administered questionnaire which consisted of questions on sociodemographic variables and substance (alcohol, nicotine, sedative-hypnotics, and illicit drugs) use and abuse. The questions about alcohol, sedative-hypnotics and illicit drugs were rated as: "never used", "used last year" and "used this month". Smoking habits were described as the number of cigarettes per day.

The participating students gave written informed consent and completed the questionnaire anonymously, using code names in their classroom during class time. Students who were absent from the classroom on the study day or did not agree to participate in the survey were excluded. Students with BAI scores $>25$ had the opportunity to talk to a psychiatrist. A standard psychiatric interview was performed only with those students who accepted the suggestion. Most of them went through a process of counselling during the next few weeks.

For statistical evaluation, Statistica 7 software was employed. The chi-square method was used for the analysis of categorical variables and the Student t-test and one-way ANOVA for continuous ones. A p-value of $\leq 0.05$ for a two-tailed test was considered significant.

\section{Results}

The value of the Chronbach alpha coefficient of internal consistency for the Macedonian version of BAI was 0.873 (Table1).

Table 1

Description of the sample and values of BAI scores in all participants

\begin{tabular}{|l|l|l|l|l|l|}
\hline Subjects & M1 & M2 & D2 & L2 & Total \\
\hline Number & 188 & 257 & 242 & 55 & 742 \\
\hline $\begin{array}{l}\text { Gender } \\
\text { Male } \\
\text { Female }\end{array}$ & 67 & 97 & 105 & 27 & 296 \\
\hline Mean age & 121 & 160 & 137 & 28 & 446 \\
\hline $\begin{array}{l}\text { Average } \\
\text { grades }\end{array}$ & $8.1 \pm 0.7$ & $19.91 \pm 1.22$ & $19.51 \pm 1.41$ & $19.64 \pm 0.98$ & $19.76 \pm 0.64$ \\
\hline $\begin{array}{l}\text { Mean BAI } \\
\text { scores }\end{array}$ & $16.8 \pm 9.8$ & $15.4 \pm 10.4$ & $14.8 \pm 9.0$ & $14.9 \pm 10.3$ & $15.5 \pm 9.9$ \\
\hline $\begin{array}{l}\text { Maximum } \\
\text { BAI score }\end{array}$ & 50 & 48 & 46 & $47.9 \pm 0.7$ & 50 \\
\hline $\begin{array}{l}\text { Minimum } \\
\text { BAI score }\end{array}$ & 1 & 0 & 0 & 0 & 0 \\
\hline
\end{tabular}

* Abbreviations: M1 - Faculty of Medicine (first academic year); M2 - Faculty of Medicine (second academic year);

D2- Faculty of Dentistry (second academic year); L2 - Faculty of Law (second academic year) 
Table 1 presents general demographic variables of the sample (gender, mean age and average grades of students), mean values and the range of BAI scores of all participants. Medical students in the first academic year showed the highest mean values of BAI scores (16.8), with a range between 1 and 50, compared to other students, but the differrences between groups were not significant $($ ANOVA F $=1.190, \mathrm{p}=0.314$ ).

The prevalence of high anxiety levels (BAI scores $>25$ ) in first year medical students was $20 \%$, while in law students it was $16.7 \%$. Fifteen percent of second year medical students and $11.3 \%$ of dentistry students had high anxiety levels. There was no significant difference between groups $\left(\chi^{2}=\right.$ $10.323, \mathrm{df}=9, \mathrm{p}=0.325)$. Of all the university students in our sample 15\% showed high anxiety levels.

Eighteen percent of all female students and $10 \%$ of all male students showed high levels of anxiety $\left(\chi^{2}=25.368, \mathrm{df}=3, \mathrm{p}=0.001\right)$.

Table 2

Item means and SDs for the BAI in all groups of students

\begin{tabular}{|c|c|c|c|c|c|c|c|c|c|c|}
\hline Item & & \multicolumn{2}{|l|}{ M1 } & \multicolumn{2}{|l|}{ M2 } & \multicolumn{2}{|l|}{ D2 } & \multicolumn{2}{|l|}{ L2 } & $\mathrm{p}$ \\
\hline 1. & $\begin{array}{l}\text { Numbness and } \\
\text { tingling }\end{array}$ & 0.56 & 0.79 & 0.51 & 0.75 & 0.56 & 0.77 & 0.54 & 0.71 & 0.977 \\
\hline 2. & Feeling hot & 0.98 & 0.86 & 0.96 & 0.89 & 0.94 & 0.87 & 1.04 & 0.9 & 0.884 \\
\hline 3. & $\begin{array}{l}\text { Wobbliness in } \\
\text { legs }\end{array}$ & 0.81 & 0.98 & 0.64 & 0.87 & 0.60 & 0.84 & 0.56 & 0.80 & 0.091 \\
\hline 4. & $\begin{array}{l}\text { Unable to } \\
\text { relax }\end{array}$ & 1.20 & 1.02 & 1.05 & 1.04 & 0.93 & 0.95 & 1.0 & 1.05 & 0.111 \\
\hline 5. & $\begin{array}{l}\text { Fear of worst } \\
\text { happening }\end{array}$ & 1.21 & 1.17 & 0.97 & 1.12 & 1.02 & 1.10 & 0.94 & 1.0 & 0.165 \\
\hline 6. & $\begin{array}{l}\text { Dizzy or } \\
\text { lightheaded }\end{array}$ & 0.68 & 0.91 & 0.76 & 0.99 & 0.73 & 0.89 & 0.75 & 0.91 & 0.947 \\
\hline 7. & $\begin{array}{l}\text { Heart } \\
\text { pounding or } \\
\text { racing }\end{array}$ & 1.19 & 0.98 & 1.11 & 0.93 & 0.98 & 0.92 & 0.98 & 0.98 & 0.165 \\
\hline 8. & Unsteady & 0.61 & 0.82 & 0.65 & 0.79 & 0.55 & 0.75 & 0.69 & 0.88 & 0.078 \\
\hline 9. & Terrified & 1.16 & 0.99 & 0.86 & 0.95 & 0.9 & 0.89 & 0.81 & 0.96 & $0.015 * *$ \\
\hline 10. & Nervous & 1.54 & 1.0 & 1.57 & 0.98 & 1.53 & 0.90 & 1.71 & 1.05 & 0.203 \\
\hline 11. & $\begin{array}{l}\text { Feelings of } \\
\text { choking }\end{array}$ & 0.42 & 0.79 & 0.44 & 0.83 & 0.33 & 0.65 & 0.46 & 0.77 & 0.504 \\
\hline 12. & $\begin{array}{l}\text { Hands } \\
\text { trembling }\end{array}$ & 0.79 & 0.99 & 0.65 & 0.87 & 0.48 & 0.76 & 0.42 & 0.61 & $0.002 * *$ \\
\hline 13. & Shaky & 1.20 & 0.93 & 1.03 & 0.93 & 0.93 & 0.87 & 1.23 & 0.95 & $0.024 * *$ \\
\hline 14. & $\begin{array}{l}\text { Feeling of } \\
\text { losing control }\end{array}$ & 0.69 & 1.00 & 0.54 & 0.89 & 0.48 & 0.81 & 0.46 & 0.80 & 0.077 \\
\hline 15. & $\begin{array}{l}\text { Difficulty } \\
\text { breathing }\end{array}$ & 0.39 & 0.76 & 0.46 & 0.80 & 0.33 & 0.65 & 0.42 & 0.68 & 0.385 \\
\hline 16. & Fear of dying & 0.28 & 0.70 & 0.27 & 0.66 & 0.46 & 0.87 & 0.35 & 0.84 & 0.084 \\
\hline 17. & Scared & 1.01 & 0.97 & 0.71 & 0.87 & 0.78 & 0.81 & 0.79 & 1.05 & $0.026 * *$ \\
\hline 18. & $\begin{array}{l}\text { Abdominal } \\
\text { discomfort }\end{array}$ & 0.44 & 0.74 & 0.65 & 0.89 & 0.50 & 0.78 & 0.42 & 0.74 & 0.104 \\
\hline 19. & Faint & 0.27 & 0.60 & 0.30 & 0.64 & 0.30 & 0.62 & 0.27 & 0.57 & 0.932 \\
\hline 20. & Face flushed & 0.73 & 0.88 & 0.66 & 0.82 & 0.83 & 0.95 & 0.52 & 0.80 & 0.164 \\
\hline 21. & $\begin{array}{l}\text { Sweating (not } \\
\text { due to heat) }\end{array}$ & 0.66 & 0.92 & 0.61 & 0.86 & 0.63 & 0.86 & 0.52 & 0.77 & 0.731 \\
\hline
\end{tabular}

*Abbreviations: M1 - Faculty of Medicine (first academic year); M2 - Faculty of Medicine (second academic year); D2 - Faculty of Dentistry (second academic year); L2 - Faculty of Law (second academic year) $* * \mathrm{p}<0.05$

Table 2 As can be seen from Table 2, mean values and standard deviations of scores on each item of the Beck Anxiety Inventory from all four groups of students are presented. These scores represent the perceived intensity of a certain symptom of anxiety within the Inventory. All 
participants identified the symptoms "feeling hot" (BAI 2), "unable to relax" (BAI 4), "fear of the worst happening" (BAI 5), "heart pounding/racing" (BAI 7), "terrified" (BAI 9), "nervous" (BAI 10), "shaky" (BAI 13) and "scared" (BAI 17) as symptoms of anxiety which were perceived with the highest intensity during the past week. There were significant differences between mean values of BAI scores on items BAI 9 ("terrified") (ANOVA F $=3.107, \mathrm{p}=$ 0.015), BAI 12 ("hands trembling") (ANOVA F = 4.250, $\mathrm{p}=0.002)$, BAI 13 ("shaky") (ANOVA $\mathrm{F}=$ $2.815, \mathrm{p}=0.024$ ), and BAI 17 ("scared") (ANOVA $\mathrm{F}=2.775, \mathrm{p}=0.026$ ) between groups. First year medical students and law students experienced the highest intensity of these symptoms compared to students from other groups.

Table 3

Alcohol, nicotine, sedative-hypnotics and illicit drug use among university students

\begin{tabular}{|c|c|c|c|c|c|}
\hline Variables & $\begin{array}{c}\text { M1 } \\
\mathrm{n}=\mathbf{1 8 8}(\%)\end{array}$ & $\begin{array}{c}\text { M2 } \\
\mathrm{n}=\mathbf{2 5 7}(\%)\end{array}$ & $\begin{array}{c}\text { D2 } \\
\mathrm{n}=242 \quad(\%)\end{array}$ & $\begin{array}{c}\text { L2 } \\
\mathrm{n}=\mathbf{5 5}(\%)\end{array}$ & $\begin{array}{c}\text { Total } \\
\mathrm{n}=742(\%)\end{array}$ \\
\hline \multicolumn{6}{|l|}{ Alcohol } \\
\hline never used & $89(47.3)$ & $114(44.3)$ & $84(34.7)$ & $14(25.4)$ & $301(40.7)$ \\
\hline past year & 21(11.2) & $27(10.5)$ & $18(7.4)$ & $9(16.4)$ & $75(10.1)$ \\
\hline past month & $76(40.4)^{*}$ & $106(41.2)$ & $133(54.9)$ & $32(58.2)$ & $347(46.8)$ \\
\hline no response & $2(1.1)$ & $10(3.9)$ & $7(2.9)$ & - & $19(2.4)$ \\
\hline \multicolumn{6}{|l|}{ Nicotine } \\
\hline smokers & $39(20.7)^{*}$ & $74(28.8)$ & $80(33)$ & $17(30.9)$ & $210(28.3)$ \\
\hline no response & $2(1.1)$ & $1(0.4)$ & $3(1.2)$ & $1(1.8)$ & $7(0.9)$ \\
\hline \multicolumn{6}{|l|}{ Sedative- hypnotics } \\
\hline never used & $159(84.5)$ & $213(82.9)$ & $201(83.1)$ & $46(83.6)$ & $619(83.4)$ \\
\hline past year & $14(7.4)$ & $26(10.1)$ & $23(9.5)$ & $4(7.3)$ & $67(9.0)$ \\
\hline past month & $12(6.4)$ & $10(3.9)$ & $11(4.5)$ & $5(9.1)$ & $38(5.1)$ \\
\hline no response & $3(1.6)$ & $8(3.1)$ & $7(2.9)$ & - & $18(2.4)$ \\
\hline \multicolumn{6}{|l|}{ Illicit drug use } \\
\hline ever used & $2(1.1)$ & $6(2.3)$ & $8(3.3)$ & $2(3.6)$ & $26(3.5)$ \\
\hline no response & $3(1.6)$ & $9(3.5)$ & $7(2.9)$ & - & $19(2.6)$ \\
\hline
\end{tabular}

$* \mathrm{p}<0.05$

As can be seen from Table 3, alcohol was the most frequently used substance. $58.2 \%$ of the students from the Faculty of Law, $54.9 \%$ of dentistry students, $41.2 \%$ of the second year medical students and $40.4 \%$ of the first year medical students reported that they had used alcohol during the past month $\left(\chi^{2}=20.262, \mathrm{df}=6, \mathrm{p}=0.002\right)$. The students were categorized into three groups based on the frequency of alcohol intake. BAI scores did not differ between groups (ANOVA F $=0.52, \mathrm{p}=0.67$ ).

Tobacco smoking prevalence was highest in dentistry students (33\%), while $20.7 \%$ of first year medical students declared themselves as smokers $\left(\chi^{2}=8.204, \mathrm{df}=3, \mathrm{p}=0.04\right)$. Mean BAI scores in tobacco smokers were non-significantly higher than those in tobacco non-smokers $(\mathrm{p}=0.122)$.

Benzodiazepines (alprazolam and diazepam) were the most frequently used sedative-hypnotics. Of all participants $14.1 \%$ (105) reported that they had used sedatives during the last year, while 5.1\% $(\mathrm{n}=38)$ reported that they had done so during the past month. The highest percentage of students who had used benzodiazepines during the past month was among law students $(9 \%)$, followed by $6.7 \%(n=12)$ of first year medical students and $4.5 \%(\mathrm{n}=11)$ of dentistry students. Of all second year medical stu- dents, $3.9 \%(n=10)$ reported that they had used benzodiazepines during the past month. There was no statistical significance in frequency distribution between groups $\left(\chi^{2}=5.307, \mathrm{df}=8, \mathrm{p}=0.724\right)$. Students who reported that they had used benzodiazepines during the past month $(\mathrm{n}=38)$ showed high anxiety levels (mean BAI score $26 \pm 10.6$ ) compared to students who had never used sedatives (BAI scores $14.4 \pm 9.3)(p<0.0001)$. Multiple regression analysis for BAI as a dependent variable showed that there was a statistically significant correlation between high BAI scores and the use of benzodiazepines $\left(\mathrm{R}^{2}=0.016\right.$, beta $=0.0720$ and $\left.\mathrm{p}=0.02\right)$. There was no significant correlation between BAI scores and the use of other substances (alcohol, tobacco and illicit drugs).

The prevalence of illicit substance use was very low in all groups of students, with $3.5 \%(n=26)$ reporting that they had had experience of them. Cannabis was the most commonly used illicit substance.

\section{Discussion}

The results represent the first empirical data on the prevalence of high anxiety and substance use among cohorts of students from the medical 
sciences (Faculty of Medicine and Faculty of Dentistry) and students from social sciences (Faculty of Law) in the early stage of their education, enrolled at the biggest and oldest university in the Republic of Macedonia, "Ss. Cyril and Methodius University" in Skopje. Medical education and the medical profession are among the more stressful ones, with a huge influence on general population lifestyles and behaviours which increases the importance of the stable mental health of medical professionals. There are also reports on higher rates of anxiety and depression among first year law students, compared to the general population and to medical students $[13,20]$. Our results are consistent with these reports. The prevalence of high anxiety levels and substance use among medical and law students was similar.

The Beck Anxiety Inventory assesses the intensity of self-perceived symptoms of anxiety during a short period of time (the past week). These symptoms include physiological (symptoms of hyperarousal, such as sweating, feeling hot, palpitations, muscle tension and gastro-intestinal symptoms), and cognitive components (confusion, feeling shaky, unable to relax, fearful thoughts, nervousness, panic symptoms). In the literature on anxiety a distinction is frequently made between trait and state anxiety, especially in studies conducted in non-clinical samples (such as college students). The concept of high trait anxiety refers to a habitual tendency to be anxious over a long period of time in non-dangerous situations, which implies higher vulnerability and the development of a state of anxiety during stressful life events. State anxiety refers to a specific response of the organism to a threatening situation, and is universally experienced in the face of a threat. The intensity and the duration of the state anxiety is determined by the interaction of the situation (its duration and intensity) and personal factors (trait anxiety and defence mechanisms). BAI is a measure of current psychopathology expressed in the individual during a short period of time. In nonclinical samples it reveals the development of subclinical anxiety symptoms of short duration which are insufficient to be diagnosed as an anxiety disorder. On the other hand, in clinical samples it is a widely-used instrument for the assessment of the treatment of anxiety disorders.

The findings regarding severe state anxiety symptoms in $15 \%$ of university students in our study were consistent with the report on the prevalence of high state anxiety symptoms (23\%) among university students [19]. Twenty percent (20\%) of first year medical students and $16.7 \%$ of law students showed severe state anxiety. The symptoms that were perceived with statistically highest intensity by first year medical students and law students compared to dentistry students were of a cognitive nature (terrified, scared, nervous, shaky and unable to relax).

In our study women had significantly higher mean BAI scores and a significantly higher prevalence of high state anxiety symptoms. Also, other reports based on different measures of anxiety underscore higher anxiety scores in female students $[2,5$, $6,8]$.

Several studies report that entering medical students show a low prevalence $(0.5-2 \%)$ of high anxiety symptoms $[7,8,23]$. The increment of anxiety symptoms reaches its peak in the fifth year of training according to reports in the literature [1, 24]. In our study, of all of first-year students who were surveyed during the first month of their education $20 \%$ showed high state anxiety symptoms (BAI > 25). Second-year medical students showed a non-significant decrement of the prevalence of high state anxiety symptoms $(15 \%)$. These results suggest that medical, dentistry and law students in Macedonia are facing high psychological distress even at the onset of classes as well as during the second year of training.

The present findings regarding substance use indicate that alcohol was the most commonly used substance, followed by nicotine and benzodiazepines, which is consistent with other studies [1-8]. The prevalence of the use of illegal substances was negligible compared to that in the developed countries [1], but similar to the report from Turkey [25, 23].

The drinking rates among Macedonian junior university students were $46.8 \%$ ("current drinkers") for the whole sample. Law students showed the highest prevalence of alcohol consumption (58.2\%), followed by dentistry students $(54.9 \%)$ and second year medical students (41.2\%). First year medical students showed significantly lower drinking rates $(40.4 \%)$. The smoking rates of junior university students in Skopje (28.3\%) were similar to the ones in college students in the USA (28.5\%) [21]. Dentistry students showed the highest smoking rates (33\%) in our sample. First year medical students showed the significantly lowest smoking rates $(20.7 \%)$, while among second year medical students $28.8 \%$ were smokers. These results are in accordance with reports on smoking rates among medical students in neighbouring countries Serbia (30\%), Turkey (39.8\%), and Italy (40\% in men) $[3,4,25]$. The levels of anxiety were non-significantly higher in smokers than in non-smokers.

Benzodiazepines were the most frequently used prescribed drugs in junior university students in our sample. $14.1 \%$ reported that they had used sedative-hypnotics. Among law students $16.4 \%$ had used benzodiazepines during the past month and the 
past year. The students who reported that they had used these drugs during the current month $(\mathrm{n}=38)$ showed significantly higher levels of state anxiety $(\mathrm{BAI}=26)$ compared to those who had not used benzodiazepines $(p<0.0001)$. Sedative-hypnotic use was non-significantly higher in first year medical students compared to second year students. This is a high prevalence compared to the data from other authors who report that junior students did not use these drugs [1-3]. Our study showed that there was a significant correlation between high state anxiety levels and the frequency of benzodiazepine use in junior university students $(p=0.02)$. Bearing this in mind, the use of benzodiazepines in junior students, especially in first year university students, must be taken very seriously, knowing the fact that uncontrolled, unprescribed and long-term use of these easily-available drugs could lead to addiction and additional use of illicit drugs, with serious consequences on the health and professional engagement of these young people. The use of other substances (alcohol, tobacco and illicit drugs) among university students in our country is not statistically correlated to high anxiety levels. Our findings are in accordance with other studies which suggest that medical education does not prevent or reduce substance use, moreover it could increase it over time.

Unfinished processes of separation and individualization, lack of social relations, financial problems and worries about academic achievement and future career goals are among the leading stressors during the period of higher education. Their effects depend on the defensive mechanisms and adaptive abilities of the individual and also on the presence or absence of social and psychological support. The results from our study suggest that a portion of junior university students in our country, regardless of the curriculum of education (medicine, dentistry, law) shows high anxiety symptoms and have acquired maladaptive behaviours such as substance use (benzodiazepines) to cope with the distress. It is most important for the university facilities in our country to develop programmes and take action with the aim of helping students to acquire healthier ways of coping with psychological distress, in order to prevent the development of more serious mental disorders which are not rare in medical, dental and law professionals worldwide.

A limitation of this study is its cross-sectional character, which does not allow inference about causal associations between the investigated issues. However, it still provides important information about emotional states and lifestyles in university students at a specific (early) point in their career. This study is a start in the establishment of an inter- national and cross-cultural data-base about mental health and lifestyles among university students prospectively during their education. In this way, preventive education and therapeutic programmes can be designed to promote the personal development of each student.

\section{Conclusion}

High anxiety and substance use as maladaptive behaviours in university students are not systematically investigated in our country. The study showed that students demonstrate these types of unhealthy reactions, regardless of the curriculum of education. Our data strongly suggest that more attention should be paid to students in the early stages of their education and a student counselling service which offers mental health assistance and promotes students' intellectual, emotional and physical development should be established as an important part of the university facilities in Macedonia.

\section{REFERENCES}

1. Newbury-Birch D, Lowry R, Kamali F. The changing patterns of drinking, illicit drug use, stress, anxiety and depression in dental students in a UK dental school: a longitudinal study. Brit Dent J. 2002; 192: 646-649.

2. Akvardar Y, Demiral Y, Ergor G, Ergor A, Bilici M, Ozer A. Substance use in a sample of Turkish medical students. Drug Alcohol Depend. 2003; 72: 117-121.

3. Akvardar Y, Demiral Y, Ergor G, Ergor A. Substance use among medical students and physicians in a medical school in Turkey. Soc Psychiatr Epidemiol. 2004; 39: 502-506.

4. Vakefliu Y, Argjiri D, Peposhi I, Sejdini A, Melani SA. Tobacco Smoking Habits, Beliefs and Attitudes among Medical Students in Tirana, Albania. Prev Med. 2002; 34: 370-373.

5. Dyrbye LN, Thomas MR, Shanafelt TD. Systematic review of depression, anxiety and other indicators of psychological distress among U.S. and Canadian medical students. Acad Med. 2006; 81(4): 354-73.

6. Levine RE, Litwins BA, Frye AW. An evaluation of depressed mood in two classes of medical students. Acad Psych. 2006; 30 (3): 235-237.

7. Aktekin M, Karaman T, Senol YY. et al. Anxiety, depression and stressful life events among medical students: a prospective study in Antalya, Turkey. Med Educ. 2001; 35: 12-17.

8. Mikolajczyk RT, Maxwell AE, Naydenova V. et al. Depressive symptoms and perceived burdens related to being a student: Survey in three European countries. Clin Pract Epidemiol Ment Health. 2008; 4:19. doi: 10.1186/1745-0179-4-19.

9. Zivin K, Eisenberg D, Gollust SE, Golberstein E. Persistence of mental health problems and needs in a 
college student population. J Affect Disord. (2009) doi:10.1016/j.jad.2009.01.001.

10. Bunevicius A, Katkute A, Bunevicius R. Symptoms of anxiety and depression in medical students and in humanities students: relationship with big-five personality dimensions and vulnerability to stress. Int $\mathrm{J}$ Soc Psychiatry. 2008; 54(6): 494-501.

11. Bostanci M, Ozdel O, Oguzhanoglu NK, et al. Depressive symptomatology among university students in Denizli, Turkey: prevalence and socio-demographic correlates. Croat Med J. 2005; 46(1): 96-100.

12. Dammeyer MM, Nunez N. Anxiety and depression among law students: current knowledge and future directions. Law Hum Behav. 1999; 23(1): 55-73.

13. Preišegolavičiūtė E, Leskauskas $\mathrm{D}$, Adomaitienè V. Associations of quality of sleep with lifestyle factors and profile of studies among Lithuanian students. Medicina (Kaunas). 2010; 46(7): 482-9.

14. Andrade L, Caraveo-Anduaga J, Berglund P. Crossnational comparisons of the prevalence and correlates of mental disorders. WHO International Consortium in Psychiatric Epidemiology. Bull World Health Organ. 2000; 78: 413-26.

15. Cole DA, Peeke LG, Martin JM, et al. A longitudinal look at the relation between depression and anxiety in children and adolescents. Journal of Consulting and Clinical Psychology. 1998; 66 (3): 451-460.

16. Brown TA, Campbell La, Lehman CL, et al. Current and lifetime comorbidity of DSM-IV anxiety and mood disorders in a large clinical sample. Jour Abnorm Psychol. 2001; 110: 49-58.

17. Beck AT, Epstein N, Brown G, Steer RA. An inventory for measuring clinical anxiety: Psychometric properties. Journal of Consulting and Clinical Psychology. 1988; 56: 893-897.

18. Creamer M, Foran J, bell R. The Beck Anxiety Inventory in a non-clinical sample. Behav Res Ther. 1995; 33(4): 477-485.

19. Pritchard ME, McIntosh DN. What predicts adjustment among law students? A longitudinal panel study. J Soc Psychol. 2003 Dec; 143(6): 727-45.

20. Paterson F, Lerman C, Kaufmann VG, et al. Cigarette smoking practices among american college students: Review and future directions. Journal of American College Health. 2004; 52(5): 203-212.

21. Mehanna Z, Richa S. Prevalence of anxiety and depressive disorders in medical students in the Saint Joseph University of Beirut. Encephale. 2006; 32(6): 986-82.

22. Smith CK, Peterson DF, Degenhardt BF, Johnson JC. Depression, anxiety and perceived hassles among entering medical students. Psychol Health Med. 2007; 12(1): 31-39.

23. Chandavarkar U, Azzam A, Mathews C. Anxiety symptoms and perceived performance in medical students. Depress Anxiety. 2007; 24: 103-111.
24. Senol Y, Donmez L, Turkay M, Aktekin M. The incidence of smoking and risk factors for smoking initiation in medical faculty students: a cohort study. BMC Public Health. 2006; 6: 128.

Резиме

\section{ПРЕВАЛЕНЦИЈА НА ВИСОКА АНКСИОЗНОСТ И УПОТРЕБА НА СУПСТАНЦИИ КАЈ СТУ ДЕНТИТЕ ВО РЕПУБЛИКА МАКЕДОНИЈА}

\section{Сања Манчевска, Јасмина Плунцевиќ-Глигороска}

Институт за физиологија со антропологија, Медицински факултет, Универзитет „Св. Кирил и Методиј“, Скопје, Р. Македонија

Цел на студијата е да се одреди преваленцијата на сериозна анксиозност и употреба на супстанции кај студентите во Република Македонија. Примерокот се состои од 742 студенти на возраст од 18 до 22 години, од прва (188 студенти) и од втора година (257) на Медицински, Стоматолошки (242) и на Правен факултет (55) при Универзитетот „Св. Кирил и Методиј“во Скопје.

Како психометриски инструмент е користен Бековиот инвентор за анксиозност (БАИ). Тој претставува прашалник за самооценување којшто ја мери силината на анксиозноста. Студентите со БАИ-скорови $>29$ имаа можност да разговараат со психијатар. Користен беше и прашалник за самопополнување што содржеше прашања за навиките за користење супстанции (алкохол, никотин, седативи и нелегални дроги).

За статистичка обработка е користен пакетот Статистика 7.

Највисоки средни вредности на БАИ- скоровите беа постигнати кај студентите на Медицински факултет во прва година (16,8 \pm 9,8). Петнаесет проценти од сите студенти и $20 \%$ од студентите на Медицински факултет во прва година покажаа високи нивоа на анксиозност. Највисока преваленција на употреба на супстанции беше забележана меѓу студентите од Правен факултет.

Заклучивме дека високата анксиозност и употребата на супстанции како маладаптивни однесувања кај студентите не се систематски 
истражени во нашата земја. Студијата покажа дека студентите ги покажуваат овие видови нездрави реакции, без оглед на факултетот на кој студираат. Треба да се посвети повеќе внимание на студентите во првите години на студирањето. Потребно е организирање советувалиште за студенти во состав на Универзитетот, кое ќе обезбедува стручна помош, заедно со постојните капацитети на здравствениот систем.

Клучни зборови: анксиозност, БАИ, употреба на супстанции, советувалиште за студенти. 